\title{
HASIL BELAJAR PJOK SISWA SMP DI PROVINSI BANGKA BELITUNG SEBELUM DAN SAAT PANDEMI COVID-19
}

\author{
Muhammad Eka Mardyansyah Simbolon ${ }^{1,}$ Sigit Pra Yoga ${ }^{2}$, Peri Sagita ${ }^{3}$, Cici Cahyati ${ }^{4}$, Faisal \\ Abdillah $^{5}$, Suardian Ramadhan ${ }^{6}$, Ririn Asmarita ${ }^{7}$, Deda Mahendra $^{8}$, Mahrul $^{9}$.
}

Fakultas Keguruan dan Ilmu Pendidikan, Universitas Muhammadiyah Bangka Belitung ${ }^{1}$

Email: sigitprayoga848@gmail.com

\begin{abstract}
ABSTRAK
Covid-19 telah menyebar keseluruh dunia, bidang pendidikan ikut merasakan besarnya dampak dari virus ini. Pemerintah langsung mengambil kebijakan untuk mencegah penyebaran Covid-19 dengan melakukan pembelajaran dari rumah secara daring melalui smartphone, tidak terkecuali pembelajaran PJOK yang biasanya banyak sekali materi praktek secara langsung antara guru dan siswa. Hal ini bisa saja mempengaruhi hasil belajar siswa karena penilaian dan pengerjaan tugas yang dilakukan dengan cara yang berbeda dari sebelumnya.. Tujuan dari penelitian ini adalah untuk mengetahui bagaimana dampak pandemi Covid-19 terhadap hasil belajar PJOK siswa SMP di Provinsi Kepulauan Bangka Belitung. Metode yang digunakan dalam penelitian ini adalah deskriptif kuantitatif dengan metode survey menggunakan dokumentasi nilai rapot siswa SMP sebelum dan saat pandemi sebanyak 1003 Siswa.. Dari penelitian yang kami lakukan diperoleh hasil belajar PJOK siswa SMP di Provinsi Kepulauan Bangka Belitung mengalami penurunan pada masa Pandemi, nilai siswa lebih baik saat sebelum terjadinya pandemi.. Saat pandemi hasil belajar siswa laki-laki lebih baik di bandingkan dengan siswa perempuan. Untuk Kabupaten Bangka Tengah, Bangka Barat, Bangka Selatan dan Pangkalpinang nilai rapot PJOK mengalami penurunan, namun Kabupaten Bangka Induk justru mengalami peningkatan. Jadi, dari penelitian ini Rata-rata nilai PJOK siswa SMP di Provinsi Kepulauan Bangka Belitung mengalami penurunan saat masa Pandemi.
\end{abstract}

Kata kunci: Covid-19, Hasil belajar, pembelajaran PJOK, Bangka Belitung

\begin{abstract}
Covid-19 has spread throughout the world, the education sector has also felt the huge impact of this virus. The government immediately took a policy to prevent the spread of Covid-19 by learning from home online via a smartphone, including learning PJOK which usually has a lot of practical material directly between teachers and students. This could have affected student learning outcomes because the assessment and assignments were carried out in a different way than before. The purpose of this study was to determine how the impact of the Covid-19 pandemic on the learning outcomes of junior high school student PJOK in Bangka Belitung Islands Province. The method used in this research is descriptive quantitative with a survey method using documentation of junior high school student report cards before and during the pandemic as many as 1003 students. students were better before the pandemic. During the pandemic the learning outcomes of male students were better than female students. For Central Bangka, West Bangka, South Bangka and Pangkalpinang Districts, the value of report cards for PJOK has decreased, but Bangka Induk Regency has actually experienced an increase. So, from this study, the average PJOK score for junior high school students in the Bangka Belitung Islands Province decreased during the Pandemic
\end{abstract}

Key words: Covid-19, learning outcomes, PJOK learning, Bangka Belitung.

Dipublikasikan Oleh :

UPT Publikasi dan Pengelolaan Jurnal

Universitas Islam Kalimantan Muhammad Arsyad Al-Banjari Banjarmasin 


\section{PENDAHULUAN}

Salah satu topik yang sedang diberitakan oleh seluruh media massa secara internasional adalah mengenai Virus corona atau COVID-19. Virus yang sampai sekarang ini telah menyebar hampir ke seluruh dunia atau lebih dari 100 negara dan berhasil merenggut ribuan nyawa. World Healt Organization (WHO) telah menetapkan virus ini sebagai pandemi sehingga setiap negara harus menetapkan status nasional virus Corona (Alfaritsi et al., 2020). Pada tanggal 31 Desember 2019, WHO China Country Office melaporkan kasus pneumonia yang tidak diketahui etiologinya di Kota Wuhan, Provinsi Hubei, Cina. Pada tanggal 7 Januari 2020, China mengidentifikasi kasus tersebut sebagai jenis baru dari corona virus. Peningkatan jumlah kasus berlangsung begitu cepat dan menyebar ke berbagai negara dalam waktu singkat. Sampai dengan tanggal 9 Juli 2020, WHO melaporkan 11.84.226 kasus konfirmasi dengan 545.481 kematian di seluruh dunia (Case Fatality Rate/CFR 4,6\%). Indonesia melaporkan kasus pertama pada tanggal 2 Maret 2020. Kasus meningkat dan menyebar dengan cepat di seluruh wilayah Indonesia.(Sugihantono, 2020).

Dengan hadirnya wabah Covid-19 yang tak terduga, maka dunia pendidikan Indonesia perlu mengikuti alur yang sekiranya dapat menolong kondisi sekolah dalam keadaan darurat. Sekolah perlu memaksakan diri menggunakan media daring (dalam jaringan). Namun penggunaan teknologi bukan tidak ada masalah, banyak varian masalah yang menghambat keterlaksanaannya efektivitas pembelajaran dengan metode daring. Proses pembelajaran di sekolah merupakan alat kebijakan publik terbaik sebagai upaya peningkatan pengetahuan dan keterampilan. Selain itu banyak siswa menganggap bahwa sekolah adalah kegiatan yang sangat menyenangkan, mereka bisa berinteraksi satu sama lain. Sekolah dapat meningkatkan keterampilan sosial dan kesadaran kelas sosial siswa. Sekolah secara keseluruhan adalah media interaksi antar siswa dan guru untuk meningkatkan kemampuan intelegensi, skill dan rasa kasih sayang diantara mereka. Tetapi sekarang kegiatan sekolah berhenti dengan tiba-tiba karena dampak Covid-19. Sejauh mana dampaknya bagi proses Belajar di sekolah? Khusus untuk Indonesia banyak bukti ketika sekolah sangat mempengaruhi produktivitas dan pertumbuhan ekonomi (Syah, 2020).

Pemerintah menerapkan kebijakan Work From Home (WFH). Kebijakan ini merupakan upaya yang diterapkan kepada masyarakat agar dapat menyelesaikan segala pekerjaan di rumah. Pendidikan di Indonesia pun menjadi salah satu bidang yang terdampak akibat adanya pandemi covid-19 tersebut. Dengan adanya pembatasan interaksi, Kementerian Pendidikan di Indonesia juga mengeluarkan kebijakan yaitu dengan meliburkan sekolah dan mengganti proses Kegiatan Belajar Mengajar (KBM) dengan menggunakan sistem dalam jaringan (daring). Dengan menggunakan sistem pembelajaran secara daring ini, terkadang muncul berbagai masalah yang dihadapi oleh siswa dan guru, seperti materi pelajaran yang belum selesai disampaikan oleh guru kemudian guru mengganti dengan tugas lainnya. Hal tersebut menjadi keluhan bagi siswa karena tugas yang diberikan oleh guru lebih banyak (Siahaan, 2020). Pembelajaran sebagai suatu proses berlangsung secara dinamis karena berbagai situasi dan kondisi yang berubah-ubah dan dapat berpengaruh pada kualitas pembelajaran yang dilaksanakan. Tentunya dinamika pembelajaran yang kompleks juga memberikan dampak besar terhadap kemampuan peserta didik dalam capaian hasil pembelajaran (Mansyur, 2020).

Pembelajaran daring merupakan pembelajaran yang menggunakan jaringan internet dengan aksesibilitas, konektivitas, fleksibilitas, dan kemampuan untuk memunculkan berbagai jenis interaksi pembelajaran (Sadikin et al., 2020). Ada beberapa aplikasi yang dapat membantu kegiatan belajar mengajar, misalnya whatsapp, zoom, web blog, edmodo dan lain-lain. Pemerintah juga mengambil peran dalam menangani ketimpangan kegiatan belajar selama pandemi Covid-19 ini (Sourial et al., 2018). Konten dalam pembelajaran, multimedia dan jaringan teknologi yang berkembang dengan cepat telah membantu mengubah media tradisional, seperti buku, tabel, gambar, menulis papan, formulir online dan interaktif. Bentuk-bentuk baru dari materi pembelajaran dapat diakses oleh siswa dari mana saja dan kapan saja melalui internet (Tambunan \& Siagian, 2020). Pembelajaran online yang efektif harus mempertimbangkan berbagai faktor seperti kecepatan, rasio siswa-guru, pedagogi, peran guru online, peran siswa online, sinkronisasi komunikasi online, peran penilaian online, dan sumber umpan balik. Namun, karena desain kelas saat ini hanya solusi sementara untuk pengajaran online (Handayani, 2020). Kelemahan dalam pembelajaran daring adalah kurang maksimalnya keterlibatan siswa. Keterlibatan siswa yang dimaksud dapat dilihat dari hasil keterlibatan siswa dalam mengikuti pembelajaran daring secara penuh dari awal pembelajaran sampai akhir pembelajaran. (Anugrahana, 2020)

Pendidikan Jasmani atau Penjas (Dikjas) merupakan salah satu mata pelajaran formal, yang telah diberikan mulai dari sekolah dasar hingga sekolah menengah. Peranan Pendidikan Jasmani sangat penting, yang memberikan kesempatan kepada para siswa untuk terlibat langsung dalam proses pembelajaran melalui aktivitas jasmani, bermain dan olahraga yang dilakukan secara sistematis. Sebagai mana yang tercantum dalam garis-garis besar program pengajaran (GBPP) Yaitu," Pendidikan Jasmani bukan hanya merupakan aktivitas pengembangan fisik secara terisolasi, akan tetapi harus berada dalam konteks pendidikan secara umum.h Kekeliruan yang sering

Dipublikasikan Oleh :

UPT Publikasi dan Pengelolaan Jurnal

Universitas Islam Kalimantan Muhammad Arsyad Al-Banjari Banjarmasin 
dijumpai adalah banyak orang yang beranggapan bahwa Pendidikan Jasmani hanya berisi dengan kegiatan olahraga (Pahliwandari, 2016).

Belajar adalah suatu proses usaha yang dilakukan individu untuk memperoleh perubahan tingkah laku yang baru sebagai pengalaman individu itu sendiri..Individu dikatakan belajar atau tidak sangat tergantung kepada kebutuhan dan motivasinya. Kebutuhan dan motivasi menjadi tujuan seseorang dalam belajar. Sedangkan motivasi akan timbul jika individu memiliki minat yang besar. Faktor yang mempengaruhi proses dan hasil belajar siswa baik itu faktor dari dalam, luar, maupun instrumen yang paling utama adalah minat, motivasi, dan guru. (Martínez et al., 2013). Hasil belajar siswa merupakan salah satu tujuan dari proses pembelajaran di sekolah, untuk itu seorang guru perlu mengetahui, mempelajari beberapa metode mengajar, serta dipraktekkan pada saat mengajar. Untuk menghasilkan prestasi (hasil) belajar siswa yang tinggi, guru dituntut untuk mendidik dan mengajar siswa dengan menggunakan metode pembelajaran yang dibutuhkan dalam proses pembelajaran di kelas. Dapat dikatakan bahwa adanya hasil belajar siswa yang tinggi dan berkualitas, dapat dihasilkan dari proses pembelajaran yang berkualitas, untuk menghasilkan proses pembelajaran yang berkualitas seorang tenaga pendidik membutuhkan kemampuan dalam menerapkan metode pembelajaran yang sesuai dengan kebutuhan dalam kelas, ketidaksesuaian metode pembelajaran yang diterapkan dapat menurunkan kualitas proses pembelajaran itu sendiri, dengan demikian maka perbaikan dan peningkatan hasil belajar siswa di sekolah dapat dilaksanakan dengan adanya penggunaan metode pembelajaran yang tepat oleh guru, dengan demikan dalam penelitian ini ingin mengetahui dan menganalisis mengenai penggunaan metode pembelajaran dalam peningkatan hasil belajar siswa di sekolah. (Nasution, 2017)

.. Setiap proses pembelajaran tentunya diharapkan peserta didik memperoleh hasil belajar yang baik. Namun pada kenyataannya hasil belajar yang diperoleh siswa tidak selalu baik dan sesuai harapan. Sebagaimana yang menjadi standar baik atau tidaknya hasil belajar atas dasar KKM yang telah ditetapkan sebagai patokan keberhasilan proses pembelajaran. Hal ini harus menjadi perhatian dan bahan evaluasi dalam proses pembelajaran. Hasil belajar siswa yang belum baik menjadi salah satu permasalahan dalam pendidikan. Hasil belajar siswa menunjukkan kemampuan dan kualitas siswa sebagai dampak dari proses pembelajaran yang telah dilaluinya (Nurhasanah \& Sobandi, 2016). Berdasarkan pada Permendikbud Nomor 81A tahun 2013 (Lampiran VI), "penilaian merupakan serangkaian kegiatan untuk memperoleh, menganalisis, dan menafsirkan data tentang proses dan hasil belajar peserta didik yang dilakukan secara sistematis dan berkesinambungan, sehingga menjadi informasi yang bermakna dalam pengambilan keputusan.” (Juliandita et al., 2016)

\section{METODE}

Penelitian ini menggunakan penelitian deskriptif kuantitatif untuk mengetahui hasil belajar siswa SMP pada mata pelajaran PJOK sebelum dan saat pandemi. Dengan pendekatan one shot case study/ stadi kasus atau kesempatan. Metode penelitian ini menggunakan teknik sampling acak sederhana (Simple RandomSampling) dengan pendekatan survei, sedangkan pengumpulan datanya menggunakan dokumentasi hasil belajar siswa berupa nilai rapot. Pengumpulan data mulai dari tanggal 28 Desember 2020 sampai tanggal 12 Januari 2021. Dengan datang langsung ke sekolah atau bertemu langsung dengan guru yang bersangkutan. Penelitian ini bertujuan untuk mengetahui bagaimana Hasil Belajar PJOK Siswa SMP di Provinsi Bangka Belitung Sebelum Dan Saat Pandemi Covid-19. Hasil dapat di ketahui dari rata-rata nilai siswa dan kkm sekolah

\section{HASIL DAN PEMBAHASAN}

Pada penelitian ini hasil belajar PJOK siswa SMP di Provinsi Kepulauan Bangka Belitung sebelum dan saat pandemi di ukur dari rata-rata nilai rapot PJOK dan rata-rata KKM. Hasil belajar siswa SMP di Provinsi Kepulauan Bangka Belitung sebelum dan saat pandemi dapat dilihat pade tabel 1.1

Tabel 1.1

Data Rata-rata Nilai PJOK Sebelum dan Saat Pandemi

\begin{tabular}{llccccc}
\hline \multirow{2}{*}{ No } & \multirow{2}{*}{ Indikator } & \multirow{2}{*}{ Responden } & \multicolumn{2}{c}{ Sebelum Pandemi } & \multicolumn{2}{c}{ Saat Pandemi } \\
\cline { 3 - 6 } & & & Nilai & KKM & Nilai & KKM \\
\hline 1 & Seluruh & 1003 & 81,07 & 74,29 & 81,95 & 75,82 \\
2 & Laki-laki & 501 & 80,37 & 74,04 & 81,27 & 75,56 \\
3 & Perempuan & 502 & 81,77 & 74,53 & 82,62 & 76,09 \\
4 & Bangka Induk & 200 & 80,37 & 74,42 & 82,62 & 76,55 \\
5 & Bangka Tengah & 230 & 78,61 & 74,33 & 77,86 & 74,67 \\
\hline
\end{tabular}

Dipublikasikan Oleh :

UPT Publikasi dan Pengelolaan Jurnal

Universitas Islam Kalimantan Muhammad Arsyad Al-Banjari Banjarmasin 


\begin{tabular}{ccccccc}
\hline \multirow{2}{*}{ No } & \multirow{2}{*}{ Indikator } & \multirow{2}{*}{ Responden } & \multicolumn{2}{c}{ Sebelum Pandemi } & \multicolumn{2}{c}{ Saat Pandemi } \\
\cline { 4 - 7 } & & Nilai & KKM & Nilai & KKM \\
\hline 6 & Bangka Barat & 116 & 84,16 & 75 & 81,54 & 75 \\
7 & Bangka Selatan & 230 & 86,16 & 78 & 87,81 & 80 \\
8 & Pangkalpinang & 227 & 77,44 & 70 & 79,75 & 72,54 \\
\hline
\end{tabular}

Rata-rata nilai rapot PJOK siswa sebelum pandemi adalah 81,07 dengan KKM 74,29 dan saat pandemi mengalami peningkatan menjadi rata-rata nilai rapot PJOK 81,95 dengan KKM 75,82. Berdasarkan hasil penelitian yang telah kami lakukan untuk nilai rapot dan KKM tertinggi sebelum dan saat pandemi covid-19 menyatakan bahwa kabupaten Bangka Selatan menjadi kabupaten dengan nilai tertinggi dengan rata-rata nilai rapot PJOK sebelum pandemi 86,16, dengan KKM-nya 78 serta nilai saat pandemi 87,81 dan KKM-nya 80 dan untuk nilai terkecilnya terdapat pada kota Pangkalpinang dengan nilai rapot sebelum pandemi 77,44 dengan KKM 70 serta nilai saat pandemi 79,75 dengan KKM 72,54. Pada hasil penelitian ini siswa SMP kabupaten Bangka Induk mengalami sedikit peningkatan, Berbeda dengan ke empat daerah lainnya yang justru mengalami penurunan, Jadi dapat disimpulkan bahwa siswa SMP di Provinsi Kepulauan Bangka Belitung Mengalami penurunan pada nilai PJOK saat pandemi.

Coronavirus Disease 2019 (COVID-19) adalah penyakit jenis baru yang belum pernah diidentifikasi sebelumnya pada manusia, virus penyebab COVID-19 ini dinamakan Sars-CoV-2. Masa inkubasi rata-rata 5-6 hari dengan masa inkubasi terpanjang 14 hari. Pada kasus COVID-19 yang berat dapat menyebabkan pneumonia, sindrom pernapasan akut, gagal ginjal, dan bahkan kematian (Isbaniah, 2020). Begitu berbahayanya penyakit ini, sehingga pemerintah berupaya keras untuk menanggulangi penyebaran COVID-19 ini. Sampai saat ini belum ditemukannya obat serta vaksin untuk masalah ini sehingga jalan satu-satunya hanyalah memutus mata rantai penyebaran COVID-19 ini (Purandina \& Winaya, 2020)

Pembelajaran daring memiliki tantangan unik, tempat siswa dan guru terpisah menyebabkan guru tidak dapat mengawasi secara langsung kegiatan dalam pembelajaran terutama pada saat pemberian tugas (pekerjaan rumah). Pembelajaran online membuat interaksi siswa dengan individu lainnya jadi berkurang. Selain itu interaksi tersebut diikuti pembatasan pertemuan fisik membuat siswa bosan dan dirasakan oleh banyak kalangan di Indonesia baik di kota maupun di desa. (Rochman et al., 2020). Ketertarikan peserta didik untuk mempelajari suatu keterampilan juga disebabkan oleh metode pembelajaran. Metode pembelajaran bisa berbentuk penerapan cara- cara pembelajaran agar proses belajar bisa ber-langsung dengan baik dan tujuannya bisa tercapai (Samsudin \& Rahman, 2016). Model pembelajaran dapat ditentukan oleh guru atau dosen dengan memperhatikan tujuan dan materi pembelajaran yang akan diajarkan merujuk pada situasi dan kondisi yang terjadi di sekolah (Jayul \& Irwanto, 2020)Ditinjau dari konten dan mata pelajaran yang diajarkan di sekolah pada masa pandemi, dapat dikategorikan dalam dua kelompok. Kelompok pertama adalah kelompok mata pelajaran yang didominasi oleh teori dan sedikit praktik, sementara kelompok kedua didominasi oleh praktik dengan sedikit teori. Kedua kelompok ini sangat berbeda dalam penerapan pembelajaran online. Pendidikan Olahraga merupakan disiplin ilmu yang masuk pada kategori kedua, dengan dominasi praktik pada aktivitas fisik (Herlina \& Suherman, 2020).

Pendidikan jasmani mengandung makna pendidikan yang menggunakan aktivitas jasmani untuk menghasilkan peningkatan secara menyeluruh terhadap kualitas fisik, mental, dan emosional peserta didik. Kata aktivitas jasmani mengandung makna bahwa pembelajaran ber- basis aktivitas fisik. Kata olahraga mengandung makna aktivitas jasmani yang dilakukan dengan tujuan untuk memelihara kesehatan dan memperkuat otot-otot tubuh. Kegiatan ini dapat dilakukan sebagai kegiatan yang menghibur, menyenangkan atau juga dilakukan dengan tujuan untuk meningkatkan prestasi (Syarif, 2017). Bukan hanya fisik semata yang dibutuh untuk belajar pedidikan jasmani namun kemampuan inteligensi dan kognitif juga tidak luput dari objek pendidikan jasmani, sebagai contoh, disamping menguasai berbagai teknik dasar cabang olahraga tertentu secara praktik, peserta didik juga harus mampu menguasinya secara konseptual atau teoritis (Irwansyah, 2015). Pada usia anak SMP sangat penting untuk mengembangkan ketangkasan dan keterampilan dalam bidang olahraga serta bidang akademiknya. Penjasorkes menjadi sasaran yang tepat untuk dapat mengembang- kan berbagai keterampilan. Guru perlu membuat pembelajaran yang dapat membantu siswa dalam memahami dan mengingat suatu pembelajaran dengan baik serta penyampaian yang menyenangkan. (Fitri \& Winarni, 2016)

Banyak faktor yang mempengaruhi keberhasilan kegiatan pembelajaran sehingga perlu pemahaman atas semua faktor yang ada agar tujuan pendidikan yang terangkum dalam hasil belajar siswa dapat dicapai sesuai dengan yang diharapkan. Kesulitan belajar dapat saja datang dari siswa tetapi juga disebabkan oleh faktor

Dipublikasikan Oleh :

UPT Publikasi dan Pengelolaan Jurnal

Universitas Islam Kalimantan Muhammad Arsyad Al-Banjari Banjarmasin 
lingkungan belajarnya (Idris, 2017). Pencapaian prestasi belajar yang tinggi merupakan harapan semua siswa tercapainya prestasi siswa disekolah harus didukung oleh pihak-pihak yang ikut berperan didalamnya (Herliana, 2017). Dalam pembelajaran, penilaian merupakan serangkaian kegiatan untuk memperoleh, menganalisis dan menafsirkan data hasil belajar peserta didik yang melingkupi ranah pengetahuan, sikap dan keterampilan secara sistematis dan berkesinambungan sehingga menjadi informasi yang bermakna dalam pengambilan keputusan. Penilaian hasil pembelajaran harus dilakukan secara menyeluruh, artinya meliputi aspek pengetahuan, sikap dan keterampilan atau motorik, dan harus koprehensif, artinya penilaian dilakukan mulai dari awal (input), proses, dan keluaran (output) pembelajaran (Nasirudin et al., 2016)

Unsur-unsur yang terkait pengetahuan dan pemahaman ini adalah keterampilan merancang dan mengimplementasikan kebugaran atau program pengendalian berat badan, evaluasi kebugaran, dan keamanan dan kenyamanan berapartisipasi dalam aktivitas jasmani. Pengetahuan tentang aturan permainan, strategi, dan teknik meningkatkan partisipasi kedalam berbagai aktivitas jasmani. Permainan juga dapat meningkatkan kemampuan seseorang untuk memecahkan masalah dalam situasi emosional tertentu. Para siswa juga perlu belajar proses untuk menampilkan keterampilan fisikal dan prinsip-prinsip dasar gerakan (seperti: kesetimbangan, penyerapan daya) yang sering ada dalam berbagai aktivitas jasmani.(Setiyawan, 2019)

\section{PENUTUP}

Pandemi Covid-19 yang menyebar luas telah mempengaruhi hasil belajar PJOK siswa pada Satuan P Sekolah Menengah Pertama di Provinsi Kepulauan Bangka Belitung. Pembelajaran PJOK yang biasanya berisi materi praktek secara langsung antara guru dan siswa kini harus dilaksanakan secara terpisah, ini membuat guru dan siswa memiliki keterbatasan interaksi saat pembelajaran berlangsung. Sehingga penilaian dan pengerjaan tugas dilakukan dengan cara yang berbeda pula dari sebelumnya. Hal ini tentu berpengaruh pada hasil belajar PJOK siswa. Hasil belajar PJOK siswa pada Kabupaten Bangka Induk mengakai sedikit peningkatan. Sedangkan untuk kabupaten Bangka Tengah, Bangka Barat, Bangka Selatan dan kota Pangkalpinang mengalai penurunan. Maka dapat disimpulkan bahwa hasil belajar PJOK siswa SMP di Provinsi Kepulauan Bangka Belitung mengalami penurunan saat Pandemi Covid-19.

\section{REFERENSI}

Alfaritsi, S., Anggraeni, D., \& Fadhil, A. (2020). Analisis wacana kritis berita 'tentang social distance', cara pemerintah cegah penyebaran virus corona di Detik.com.' Jurnal Communicology, 8(1), 131-152.

Anugrahana, A. (2020). Hambatan, Solusi dan Harapan : Pembelajaran Daring Selama Masa Pandemi Covid19 Oleh Guru Sekolah Dasar. 282-289.

Fitri, A. H., \& Winarni, S. (2016). Model pembelajaran integratif penjasorkes materi atletik dengan pendidikan IPA materi Biologi untuk siswa SMP. Jurnal Keolahragaan, 4(1), 1. https://doi.org/10.21831/jk.v4i1.8108

Handayani, L. (2020). Keuntungan, Kendala dan Solusi Pembelajaran Online Selama Pandemi Covid-19 : Studi Ekploratif di SMPN 3 Bae Kudus Lina Handayani. 1(2), 15-23.

Herliana, M. N. (2017). Hubungan Peran Kepemimpinan Kepala Sekolah, Iklim Organisasi Sekolah Dan Kinerja Guru Dengan Prestasi Belajar Pendidikan Jasmani Olahraga Kesehatan Siswa Smp Negeri Se-Kota Tasikmalaya. Journal Sport Area, 2(2), 44-52. https://doi.org/10.25299/sportarea.2017.vol2(2).880

Herlina, \& Suherman, M. (2020). Potensi Pembelajaran Pendidikan Jasmani Olahraga Dan Kesehatan ( PJOK ) Di Tengah Pandemi Corona Virus Disease ( COVID ) -19 Di Sekolah Dasar. 0383.

Idris, M. (2017). Muhammad Idris - Pembelajaran Kooperatif Student Teams Achievement Division (STAD) .... $3(1), 41-50$.

Irwansyah, D. (2015). Hubungan Kecerdasan Kinestetik Dan Interpersonal Serta Intrapersonal Dengan Hasil Belajar Pendidikan Jasmani Di MTsN Kuta Baro Aceh Besar. Jurnal Administrasi Pendidikan : Program Pascasarjana Unsyiah, 3(1), 92-107.

Isbaniah, F. (2020). Dokumen resmi. Pedoman Pencegahan Dan Pengendalian Corona Virus Disease (COVID19), 0-115.

Jayul, A., \& Irwanto, E. (2020). Model Pembelajaran Daring Sebagai Alternatif Proses Kegiatan Belajar Pendidikan Jasmani di Tengah Pandemi Covid-19 Achmad. Jurnal Pendidikan Kesehatan Rekreasi, 6(2), 190-199.

Juliandita, E., Rezeki, S., \& Setyawan, A. A. (2016). Pengembangan Perangkat Penilaian Kognitif. Jppm, 9(2), $250-256$.

Mansyur, A. R. (2020). Dampak COVID-19 Terhadap Dinamika Pembelajaran Di Indonesia. Education and Learning Journal, 1(2), 113. https://doi.org/10.33096/eljour.v1i2.55

Martínez, J. F., Santibanez, L., \& Mori, E. E. S. (2013). Minat Dan Motivasi Dalam Meningkatkan Hasil Belajar

Dipublikasikan Oleh :

UPT Publikasi dan Pengelolaan Jurnal

Universitas Islam Kalimantan Muhammad Arsyad Al-Banjari Banjarmasin 
Siswa. Teachers College Record, 115(10), 11-21.

Nasirudin, N., Setiawan, I., \& Yani, A. (2016). Modul Guru Pembelajar Sejarah.

Nasution, M. K. (2017). Penggunaan metode pembelajaran dalam peningkatan hasil belajar siswa. STUDIA DIDAKTIKA: Jurnal Ilmiah Bidang Pendidikan, 11(1), 9-16.

Nurhasanah, S., \& Sobandi, A. (2016). Minat Belajar Sebagai Determinan Hasil Belajar Siswa. Jurnal Pendidikan Manajemen Perkantoran, 1(1), 128. https://doi.org/10.17509/jpm.v1i1.3264

Pahliwandari, R. (2016). Penerapan Teori Pembelajaran Kognitif Dalam Pembelajaran Pendidikan Jasmani Dan Kesehatan. 154-164.

Purandina, I. P. yoga, \& Winaya, I. M. A. (2020). Pendidikan Karakter di Lingkungan Keluarga Selama Pembelajaran Jarak Jauh pada Masa Pandemi COVID-19. Cetta: Jurnal Ilmu Pendidikan, 3(2), 270-290. https://doi.org/10.37329/cetta.v3i2.454

Rochman, B., Indahwati, N., \& ... (2020). Identifikasi Keterlaksanaan Pembelajaran PJOK Tingkat SMP Di Masa Pandemi Covid 19 Se-Kabupaten Sidoarjo. Jurnal Ilmiah ..., 6(1), 257-265. http://ejournal.mandalanursa.org/index.php/JIME/article/view/1343

Sadikin, A., Hamidah, A., Pinang, K., Jl, M., Ma, J., Km, B., Indah, M., Jaluko, K., Kode, K. M., \& Indonesia, P. (2020). Pembelajaran Daring di Tengah Wabah Covid-19 (Online Learning in the Middle of the Covid-19 Pandemic ). 6(1), 214-224.

Samsudin, S., \& Rahman, H. A. (2016). Pengaruh metode pembelajaran drill, bermain, dan kelincahan terhadap kemampuan passing dalam permainan bola voli. Jurnal Keolahragaan, 4(2), 207. https://doi.org/10.21831/jk.v4i2.10899

Setiyawan. (2019). Visi Pendidikan Jasmani dan Olahraga. Jurnal Ilmiah PENJAS, 3(October 2013), 1-224.

Siahaan, M. (2020). Dampak Pandemi Covid-19 Terhadap Dunia Pendidikan. Jurnal Kajian Ilmiah, 1(1), 73-80. https://doi.org/10.31599/jki.v1i1.265

Sourial, N., Longo, C., Vedel, I., \& Schuster, T. (2018). Pembelajaran Daring Sebagai Upaya Study From Home (SFH) Selama Pandemi Covid 19. Family Practice, 35(5), 639-643. https://doi.org/10.1093/fampra/cmy005

Sugihantono, A. (2020). Pedoman Pencegahan dan Pengendalian Corona Virus deases (Covid-19). Kementrian Kesehatan, 5, 178. https://covid19.go.id/storage/app/media/Protokol/REV-05_Pedoman_P2_COVID19_13_Juli_2020.pdf

Syah, R. H. (2020). Dampak Covid-19 pada Pendidikan di Indonesia: Sekolah, Keterampilan, dan Proses Pembelajaran. SALAM: Jurnal Sosial Dan Budaya Syar-I, 7(5). https://doi.org/10.15408/sjsbs.v7i5.15314

Syarif, A. (2017). Peningkatan hasil belajar lompat jauh gaya jongkok dengan menggunakan rekaman visual. Jurnal Keolahragaan, 5(2), 112. https://doi.org/10.21831/jk.v5i2.5733

Tambunan, N., \& Siagian, I. (2020). Analisis Lingkungan Belajar dan Aktivitas Belajar Daring Siswa SMP pada Masa Pandemi Covid-19. 2, 371-382.

Dipublikasikan Oleh :

UPT Publikasi dan Pengelolaan Jurnal

Universitas Islam Kalimantan Muhammad Arsyad Al-Banjari Banjarmasin 